\title{
Research on Teaching Mode of Higher Vocational Colleges under the Background of Mobile Internet
}

\author{
Lingyun Yang \\ Urban Vocational College of Sichuan \\ Chengdu, China
}

\begin{abstract}
A new mode of mobile Internet teaching must be constructed. The paper studies the teaching changes in this mode from the aspects of teaching contents, teaching forms, learning methods and reconstruction of teaching resources, and also studies the innovation in this condition and the teaching strategies of blended learning.
\end{abstract}

Keywords-mobile internet; higher vocational colleges; teaching mode

\section{INTRODUCTION}

Education is a people-oriented activity [1]. However, the traditional classroom teaching is knowledge-based and teacher-centered. It emphasizes the imparting of knowledge and fundamentally loses its overall concern for the existence and development of human beings [2]. The traditional classroom teachers take a commanding position, students have been in a passive state of learning, and such a uniform teaching scene can not inspire students' creativity and exploration. Dull class teaching hardly arouses the enthusiasm and positivity for learning. Therefore, it is imminent to explore a new studentoriented and student-centered teaching mode. At the same time, the rapid development of mobile Internet technology provides a beautiful blueprint for the emerging teaching mode of "Mobile Internet + Education." Therefore, it is inevitable to introduce mobile devices such as mobile phones into the field of education and into the classroom teaching, which is in line with the mighty development trend of human history and the basic educational concept of care, love and respect.

\section{THE CONNOTATION OF MOBILE INTERNET TEACHING MODE}

The main carrier of "mobile Internet teaching mode" is the mobile communication devices that are used by everyone in daily life, such as smartphones, tablet computer, laptops and so on. By the mobile Internet technology, everywhere WIFI and communication network is provided, the mode can be used to make timely teaching and learning activities. Compared with the current "MOOC ", "Micro Class", "Flip Class" popular in the teaching field, this mode has four characteristics: first, the production and use of teaching resources further highlight the Internet thinking; second, it can achieve not only the timely "Flip", but also the constant generation of teaching and learning, breaking the boundaries of teaching and learning; third, it can develop the team coordination, communication, harmonization and thinking skills of learners, promote the formation of multiple value choices and judgments, build the ability to choose, classify and reconstruct a huge information, and promote the formation of comprehensive vocational capacity of students; fourth, it make the membership structure of the learning system more abundant and reasonable, it can maximize the introduction of industry, employers and experts in participating in education and learning, so as to make the vocational education find a new way and idea in access to the industry, society and business. Within the system, everyone can be the provider of information, everyone may be the recipient of information, the division of teaching and learning is broken in the system, the role of teachers and students get out of focus, class flip occurs at any time, and the class becomes more balanced.

\section{THE IMPACT OF MOBILE INTERNET ON THE TRADITIONAL TEACHING MODE}

\section{A. Changes in Teaching Content}

The traditional textbooks are not updated for several years or even a dozen years, and now they are changed into the internet information resource bases that adapt to the development of the times and meet the different needs. In the resource base, the knowledge has a large capacity, a fast update and a significantly increased stacking speed. Students can enjoy the teaching resources with real-time updates, which are seamlessly connected with the real work scene. For students, the mobile Internet opens the door to a new world for them, but it is a new challenge for teachers who must teach students how to filter and use the diversified Internet resources.

\section{B. Changes in Teaching Form}

In the traditional teaching, teachers impart their knowledge, experience, skills to students mainly through teaching, counseling, demonstration and other ways, and teachers become the main source of information and the center of the class. In the mobile Internet environment, teachers have no longer outstanding advantages in the source of information, and they are no longer the center of the class, while teachers become the director in the class, and students become the center of the class. Teachers should instruct students to learn knowledge by using the mobile Internet to teach them how to use various online teaching resources, and guide students to gradually adapt to self-study. Finally, teachers should adapt to the unprecedented changes in working hours. 


\section{Changes in Learning Methods}

In the traditional classroom, students passively accept the knowledge in a single form, and the introduction of mobile Internet allows students to take the initiative to participate in teaching interaction. Students' learning is changed from passive acceptance into active exploration. First of all, the use of mobile Internet achieves the interaction of class subjects; second, the use of mobile Internet achieves students' selflearning after class.

\section{Reconstruction of Teaching Resources}

Traditional teaching resources are mainly based on students' books and teachers' lesson plans, while under the mobile Internet teaching mode, teaching resources are reconstructed. The common forms of reconstruction are: boutique resources sharing class, micro class, MOOC, and online courses and so son. Mobile Internet enables teachers to have richer form, diversified methods and broader perspectives in their knowledge teaching and skills training, so as to make learners learn choice, judgment and summarization in their knowledge learning and application. The learning mode of search can also encourage teachers to re-construct education and teaching content, to design teaching with a open thinking, to treat the professional ability formation with a view of future development, and to complete the choice of knowledge, classification and reconstruction with the values of diversity; guided by the mainstream value and in the atmosphere of equality and respect, to make students build the cooperation, communication, harmonization and thinking skills in the learning team, and to promote the formation of students' comprehensive vocational ability and the closure of the wisdom education system.

\section{THE INNOVATION STRATEGY OF TEACHING MODE UNDER THE BACKGROUND OF MOBILE INTERNET}

\section{A. Change the Teaching Type of "Lecturing throughout the Whole Class" by Teachers and "Receiving Knowledge Like a Container" by Students}

In the teaching mode of mobile Internet, everyone can be the provider of information. Everyone may be the receiver of information. The division of teaching and learning is broken in the system, the role of teacher and student is out of focus, class flip begins at any time, and the class gets balanced. Teachers are the managers of social group, but also the participants. Parents, students, industry experts and business elites are the masters of social groups. Each member can make interaction and exchange and answer doubts and questions through voice, text, pictures and videos in social group, so as to enhance experience, enrich knowledge and strengthen ability, and further to make education truly "face everyone" and make all learn communication and wisdom. In such a class, teachers no longer speak throughout the class and students become the masters and no longer only the container of receiving knowledge.
B. Change the One-Way Responsibility Subject Such as "Vocational Education Being the Responsibility of Education", and Realize the Participation of Enterprises and Society in Education so as to Make the Vocational Education Innovatively Achieve "Cooperation between Schools and Enterprises"

The social group established in the mobile Internet teaching model includes teachers, students, industry experts, business elites, parents and social members and so on. Such a membership structure enriches the perspectives of members of the group and broadens the breadth and scope of knowledge, to make the system full of vitality and survivability for the development of vocational education; through the guidance of teachers and group experts, industry elites and students, new knowledge produces to break the boundaries of the book, which will greatly expand the default and capacity knowledge learning. Enterprises "enter" all kinds of social groups, businesses and education stand together at any time to share the responsibility of education, so that "school-enterprise cooperation" has become a normal state.

\section{Change the Teacher's Worry of Mobile Phones in Class, and Make Mobile Phones Become an Assistant and Carrier of Education}

Education is a people-oriented activity. Educators should think actively about how to use the modern science and technology to construct the multilateral education and information interaction between educates and them, and to form effective communication and exchange between them, to form a scientific, rational, pleasant and positive educational experience and self-examination, and to establish the high-end transmission means of knowledge, skills, personality, selfcultivation and ability. Therefore, while paying attention to the all-round development and lifelong development of educatees, educators should fully respect the right and personality of educates; when facing the fact that mobile phones are inseparable from the daily life of students, actively guide them in the methods and techniques so as to set up a good relationship of trust, care and love between the educators and educates by way of respect and understanding, thus to truly realize the special role of mobile Internet in the relationship between teachers and students, between students, between campus and society, to make vocational education touch and apply modern science and technology, respect human rights, respect individual development, and further make people have competence and wisdom in life and in technology.

\section{CONCLUSION}

The teaching mode of higher vocational colleges based on mobile Internet is another exploration for reform and innovation of higher vocational education. It is a scientific innovation in the development of science and technology and in the future education, meeting the requirements of the "Internet + " era. It has played an important role in promoting the quality of personnel training. The practice and exploration of the mobile Internet teaching mode has not only changed the form of classroom teaching, but also changed the state of students' learning, to effectively dealt with the problem of "hardly learning and difficult learning" for students in 
vocational colleges, and to make students have the selfconfidence of learning and interpersonal communication, so that students become more lively and active in class, the interaction among them becomes more frequent and natural, the discussion becomes more full and positive, and the learning effect becomes more obvious.

However, during the implementation process, we also found the following problems, which will be further improved in the future.

\section{A. The Mobile Learning Resources Base Should Be Perfected}

High-quality education content is the core of mobile Internet education, and the mobile Internet teaching mode makes great use of network resources, but how to achieve the mutual conversion of existing digital math resources and mobile learning resources and to construct a reasonable and effective mobile learning repository needs a further continuous research in future.

\section{B. The Self-discipline Training Strategy for Students Should Be Further Strengthened}

The mobile Internet teaching mode is mainly to apply smart phones, tablet computers and laptop computers as learning tools in class, to guide students' interest and solve problems, for which students' attention can be attracted in learning. But some students have no enough self-control and are easily interfered, for which, the self-discipline training for students is more important, compared with the timely supervision of teachers,. Therefore, in the future research, it is necessary to further strengthen the effective self-learning and self-discipline cultivation of students in this mode.

\section{REFERENCES}

[1] Zhang Nianmeng, Education Is A People-Oriented Social Activity - A New Understanding of the Nature of Education [J], XueYuan: scholar's spiritual home, 2009 (1): 11-14

[2] Wen Ming, Chao Bo. Analysis and Reflection of Traditional Teaching Methods [J], E-Journal of New Era of Education: Teacher Edition, 2014 (20) 